\title{
Social Workers' Interpretation of and Attitude to Standards for Quality in Social Services with Focus on Human Rights
} Markéta Elichová, Anna Sýkorová

In our democratic society helping the disadvantaged is based on a general recognition of basic human rights. This recognition is the foundation of all subsequent forms of concrete help. Human rights are therefore crucial to social work. Social work is grounded in the idea of universal human rights, which are listed in international legal documents (e.g. international human rights conventions ratified by the Czech Republic') and national legal documents. ${ }^{2}$ The recognition of universal human rights is the foundation of all social work in various types of social services as concrete form of help. Providers of social services must always respect the basic human rights of users, since it is an important starting point of their work, as confirmed by A Voluntary European Quality Framework For Social Services, which states that social services supporting socially disadvantaged individuals with the goal of increasing the quality of their life and maximally integrating them in society, ${ }^{3}$ maintaining or regaining their position in community, in the majority society, in their natural community, ${ }^{4}$ are key instruments of securing basic human rights and human dignity. ${ }^{5}$

Respecting human rights in institutions providing social services is guaranteed by the state by means of supervision and licencing. ${ }^{6}$ Since 1989 a greater need to respect the human rights and dignity of social services users has developed, which used to be a neglected sphere of interest. The resulting need for supervising the quality of providing social services and respecting human rights was the main reason why quality standards for social services were developed. ${ }^{7}$

In 2002 the Ministry of Labour and Social Affairs of the Czech Republic (further MoLSA) published a general methodology for implementing standards for quality in social services (further SQSS) in practice. The standards were developed in cooperation with representatives of the expert public, providers as well as users of social work. Implementing the standards in organisations was voluntary. At the same time the validity of standards and methodology of supervising them in providers was being tested. The standards were compared with the standards for quality in social services of some European countries and comprised the principles of traditional systems of ensuring the quality of services. As part of a Czech-British project voluntary pilot inspections took place in 2002 in various social services facilities. ${ }^{8}$ In 2007 the law no. 108/2006 Sb., concerning

1 Among the most important there is the Charter of Fundamental Rights and Freedoms, International Covenant on Civil and Political Rights, International Covenant on Economic, Social and Cultural Rights, European Convention for the Protection of Human Rights and Fundamental Freedoms, Universal Declaration of Human Rights.

2 Cf. Oldřich MATOUŠEK a kol., Encyklopedie sociální práce, Praha: Portál, 2013, pp. 158-160.

3 Cf. Oldřich MATOUŠEK, Sociální služby: legislativa, ekonomika, plánování, hodnocení, Praha: Portál, 2011, pp. 9-10.

4 Cf. MoLSA ČR, Bílá kniha v sociálních službách, konzultační dokument, MoLSA, 2003, p. 8. At http://www.mpsv.cz/files/clanky/736/ bila_kniha.pdf, retrieved November 16, 2013.

5 Cf. MoLSA ČR, Dobrovolný evropský rámec pro kvalitu sociálních služeb, Výbor pro sociální ochranu, 10. 8. 2010, p. 4. At http://www.mpsv. cz/files/clanky/10768/QF_document_100707_CZ_korekce.pdf, retrieved November 16, 2013.

6 Cf. Oldřich MATOUŠEK, Sociální služby: legislativa, ekonomika, plánování, hodnocení, p. 11.

7 Cf. Pavel ČÁMSKÝ - Jan SEMBDNER - Dagmar KRUTILOVÁ, Sociální služby v ČR v teorii a praxi, Praha: Portál, 2011 , p. 17.

8 Cf. Jaroslava SÝKOROVÁ a kol., Standardy kvality sociálních služeb: metodika pro zavádění standardu kvality sociálních služeb č. 2 - Ochrana práv 
social services, came into effect, which fundamentally changed the attitude to SQSS by directly including upholding the standards for quality in social services among the duties of social services providers. At present standards for quality in social services are a set of measurable and verifiable criteria intended to allow for evidentially assessing the quality of the service provided. ${ }^{9}$

Social services aim to help those who do not have equal opportunities. They thus help disadvantaged persons to equalize their chances of social realization, 10 "since every human being as an individual has a value not derived from her position and merits." 11 This practical manifestation of social work ethos, i.e. service, solidarity, liberation, and commitment for the poor and the weak is strongly related to Christianity and its conception of serving one's neighbours. "12 "The Christian premise that all human beings are God's creatures, in the presence of God they are equal and each is neighbour to each appears here in new form. There is no exception to the imperative of solidarity in contemporary Western law, as well as in Christianity."13 Solidarity grounded in the Christian conception of neighbour is thus one of the foundations of modern social work, ${ }^{14}$ the idea of social integration is one of its pillars and is closely connected with the idea of quality of life. ${ }^{15}$ And one of the strong points of SQSS is precisely the emphasis on protecting the rights and dignity of clients and reinforcing their rights. ${ }^{16}$

\section{Human rights in Standards for quality in social services}

One of the pivotal topics of SQSS is the topic of protecting human rights. ${ }^{17}$ The level of upholding the rights of social services users is also considered to be one of the main criteria of the quality of a social service. ${ }^{18}$ The law concerning social services directly states that social services must be provided in the interest of persons and in appropriate quality in such ways that upholding the human rights and basic freedoms of persons is always consistently ensured. ${ }^{19}$

The most important human rights and freedoms that social services providers must especially take care to uphold are personal freedom and freedom of movement, right to protection of privacy and personal integrity, right to personal and family life, right to dignified treatment, right to free decision, right to proportionate risk, right to own property, right to work and reward, right to education, and right of complaint. ${ }^{20}$

uživatelů sociálních služeb v pobytových zařízeních pro seniory. Aplikační príručka pro poskytovatele, uživatele a zřizovatele, Praha: Český helsinský výbor, 2004, p. 9.

9 Cf. law no. 108/2006 Sb., concerning social services; Dagmar LAHNEROVÁ, Zavádění standardů kvality sociální péče do praxe v zařizeních sociální péče pro seniory, diploma thesis, Masarykova univerzita, Fakulta sociálních studií, supervisor Mirka Nečasová, 2008, p. 26. At http:// is.muni.cz/th/68209/fss_m/, retrieved November 9, 2013.

10 Cf. Oldřich MATOUŠEK, Sociální služby: legislativa, ekonomika, plánování, hodnocení, p. 10.

11 Ibid.

12 Cf. Jakub DOLEŽEL, Biblické kořeny sociální práce, in: Praktická teologie pro sociální pracovníky, ed. Michael MARTINEK, Praha: JABOK Vyšší odborná škola sociálně pedagogická a teologická, 2008, p. 26.

13 Oldřich MATOUŠEK, Sociální služby: legislativa, ekonomika, plánování, hodnocení, p. 10.

14 Cf. Oldřich MATOUŠEK a kol., Encyklopedie sociální práce, pp. 147-149.

15 Cf. ibid.

16 Cf. Ondřej MÁTL - Milena JABŮRKOVÁ, Kvalita péče o seniory, ř́zení kvality dlouhodobé péče v ČR, Praha: Galén, 2007, p. 44.

17 Cf. supplement no. 2 of ordinance no. 505/2006 Sb., by which some provisions of the law concerning social services are implemented.

18 Cf. Jiří SOBEK, Lidská práva v každodenním životě lidí s mentálním postižením: příručka pro zaměstnance sociálních služeb, Praha: Portus Praha, 2010, pp. 7 and 29. Cf. Pavel ČÁMSKÝ - Jan SEMBDNER - Dagmar KRUTILOVÁ, Sociální služby v ČR v teorii a praxi, pp. 16-17 and 89.

19 Cf. law no. 108/2006 Sb., concerning social services.

20 Cf. Dagmar KRUTILOVÁ, Sociální služby: tvorba a zavádění Standardi̊ kvality poskytovaných sociálních služeb, Tábor: ABENA, 2008, pp. 60-66; 
In the context of social services one of the most important human rights is taken to be the right to free decision, to which almost all other human rights and freedoms are fundamentally related. ${ }^{21}$ Freedom of choice is closely linked to individual freedom. An individual's acting as manifestation of the will is immediately related to knowledge of reality. If a human being is to be free not only in her decisions, she must have access to knowledge - i.e., to relevant information. Thus freedom of decision cannot be realized without sufficient access to information..$^{22}$ For social services users the right to free decision and its upholding is fundamental. In practice this right means the possibility to adjust the course of social service according to one's requirements and thus individualize the service with respect to one's needs, wishes, and requirements.

Freedom of decision is also indivisibly linked to responsibility for one's decisions. One of the rights related to this is the right to proportionate risk. Many social services users - especially of some types of services - find it difficult to realize their responsibility for their decisions, and therefore also to face the consequences. It is therefore necessary to work with the users and help them become aware of their responsibility when making decisions, of the possible risks and consequences. A service ought to guide the users to be able to make decisions themselves, to be able to evaluate the situation, to recognize possible solutions, analyse the risks and become aware of possible consequences. ${ }^{23}$

According to SQSS and law no. 108/2006 Sb., social services providers are obliged to ensure that the human rights and freedoms of users are protected, at present mostly in the form of elaborating a methodology (set of rules), which has gradually become a priority: "Has a methodology, acts accordingly." ${ }^{24}$ One of the most problematic aspects of the obligation to create rules is the separation of theory (i.e., rules, methods, methodology) and practice (application of rules), as confirmed e.g. by the findings of Lenc, ${ }^{25}$ or Musil who states that organizations may find attractive purely administrative upholding of SQSS which is not really reflected in the attitude to clients. ${ }^{26} \mathrm{~A}$ situation may therefore arise when the provider has written elaborate sets of rules and methodology which are not applied and used in practice. Such situation mostly arises when the methodologies to individual standards are developed by a work team that does not comprise all the employees of the organization, including workers in direct care, as confirmed e.g. by the findings of inspections carried out in the Moravian-Silesian region, especially with respect to residential services. ${ }^{27}$ This difference between theory and practice in the sphere of SQSS concerning protection of human rights is also confirmed by a probe carried out among social workers, the results of which are described below.

\footnotetext{
Pavel ČÁMSKÝ - Jan SEMBDNER - Dagmar KRUTILOVÁ, Sociální služby v ČR v teorii a praxi, pp. 93-103.

21 Cf. Dagmar KRUTILOVÁ, Sociální služby: tvorba a zavádění Standardů kvality poskytovaných sociálních služeb, p. 61; Jiř̌́ SOBEK, Lidská práva $v$ každodennim životě lidí s mentálním postižením: príručka pro zaměstnance sociálních služeb, pp. 11 and 61; Pavel ĆÁMSKÝ - Jan SEMBDNER Dagmar KRUTILOVÁ, Sociální služby v ČR v teorii a praxi, p. 95.

22 Cf. Jiří JANKOVSKÝ, Etika pro pomáhající profese, Praha: Triton, 2003, p. 38.

23 Cf. Jiří SOBEK, Lidská práva v každodenním životě lidí s mentálním postižením: př́ručka pro zaměstnance sociálních služeb, pp. 31-33.

24 Cf. QUIP - projektová zpráva k 7. lednu 2013, Individuální projekt MPSV: Inovace systému kvality sociálních služeb, 2013 , p. 7.

25 Cf. Drahomíra LENCOVÁ, Význam standardů kvality sociálních služeb ve společnosti Ledax o.p.s., České Budějovice, Jihočeská univerzita, Katedra praktické teologie, bachelor's thesis, supervisor Michal Opatrný, 2013, pp. 34-54. At https://wstag.jcu.cz/StagPortletsJSR168/Kvali fPraceDownloadServlet?typ=1\&adipidno=25438, retrieved November 15, 2013.

26 Cf. Libor MUSIL - Olga HUBÍKOVÁ - Kateřina KUBALČÍKOVÁ, Kultura poskytování osobních sociálních služeb: Případová studie pečovatelské služby. Zpráva ze druhé fáze výzkumu, Brno: Výzkumný ústav práce a sociálních věcí, 2002, p. 18.

27 Cf. (c) Zjištění z provedených inspekcí kvality sociálních služeb. Moravskoslezský kraj, 2013 (on-line), at http://verejna-sprava.krmoravskoslezsky.cz/cz/zjisteni-z-provedenych-inspekci-kvality-socialnich-sluzeb-13555/, retrieved November 15, 2013.
} 


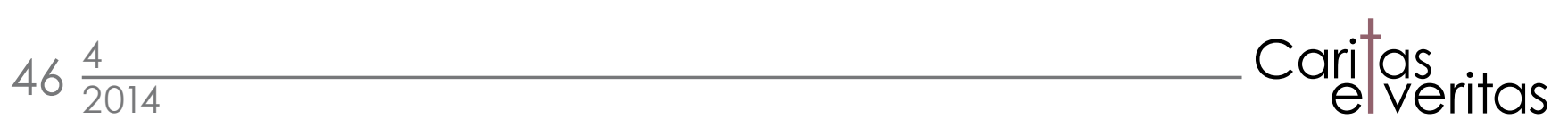

\section{How protection of users' rights is perceived by social workers}

In August and October 2013 we conducted a probe among social workers in various types of social services in the South-Bohemian region (non-residential, field, residential). We intentionally chose services for a higher-risk target group from the point of view of human rights protection - services whose target group comprises users with impaired communication ability (seniors, persons with a mental and combined disadvantage, mentally ill persons), because persons with impaired communication ability, whether permanently or temporarily, occur across the typology of services, and yet their needs are still often neglected. ${ }^{28}$ We selected respondents by means of the snowball sampling method beginning with four organizations providing social services. From the respondents we obtained further contacts to organizations and social workers. Data is still being gathered, here we present data from seven respondents. The probe is accomplished by means of semi-structured interviews and evaluates the attitude of social workers to standards for quality in social services and selected criteria bearing on the topic of values and protection of user rights and freedoms.

We selected the criteria of standards on which to focus in the interviews by identifying paragraphs listing rights and values relevant to social services users in the Charter of Fundamental Rights and Freedoms. ${ }^{29}$ Of the SQSS we focused on procedural standards, because they are most important for the organization's orientation and conception and are decisive from the point of view of protecting the rights of users and mechanisms ensuring that they are upheld. We then assigned the selected paragraphs of the Charter to individual standards and criteria in which these rights and values occur (e.g. human dignity and freedom of decision in some sense occurred in all selected standards and criteria). We selected the standards and criteria bearing on the highest number of rights and freedoms of users. On comparing with the Charter of Fundamental Human Rights and Freedoms we selected the following standards and criteria for the interview: 1b) exercising the users' will in solving their unfavorable situation; 1d) internal rules for protecting persons from bias and negative evaluation; 2 personal rights protection; 3 dealing with service applicant; 4 social service providing contract; 5 individual planning. Within the individual standards and criteria we focused on social services users with impaired communication ability.

The interviews were conducted with social workers educated according to the currently valid law concerning social services. There were seven respondents, six social workers with university education, one with higher vocational education in social work.

In the following text we focus on situations in which the rights of users are not upheld or respected - situations in which "something is wrong", as stated by respondents or identified in the course of the interview. For the sake of length the following text does not take into account situations when the respondents stated that users' rights are not violated. In many cases workers generally claimed that all is fine and users' rights are upheld, but on closer analysis of topics the answers showed that not all is fine and that there are certain gaps in upholding users' rights. Only one respondent directly stated that her institution is deficient in upholding users' rights. On the other hand, more than half the respondents admitted grave problems with individual planning.

28 Cf. Martina MÁTLOVÁ, I my jsme občané! Jak zpř̌stupnit úr̆ady i lidem s bariérami v komunikaci, Praha: Společnost pro podporu lidí s mentálním postižením v České republice, 2010, pp. 3-15.

29 The following paragraphs: 1, 2, 3 (3), 5, 6, 7, 8 (1), $10(1,2), 12(1), 14,15,17(1,2), 30(1), 31,35$ (1), 36 (1). 
On the whole, the workers addressed perceive protecting users' rights in SQSS as their important part, but only at the general level. Answers to questions focusing more specifically on individual standards and criteria were different in individual institutions. There was overall consensus of respondents in that they believe that their institution supports users in deciding and expressing their will to the maximum possible degree. In one of the institutions one of the authors was gaining work experience in the past and knows from experience that there are some deficiencies in supporting users with impaired communication ability in deciding and expressing their will. The facility does not employ techniques of augmentative or alternative communication. Some users with markedly impaired communication ability, who are almost incapable of communicating verbally, are thus deprived of the possibility to communicate in another form, which we perceive as a violation of the freedom to search out, receive, and distribute information and ideas on an equal basis with others, by means of all forms of communication according to own choice, as the freedom is specified by the Convention on the Rights of Persons with Disabilities. ${ }^{30}$

Social workers found it difficult to name rights related to exercising the user's will. Respondents admitted that they had not thought about it that way before and randomly named rights most commonly applied in their institution, e.g. right to privacy, right to choice of activity, right to rest. And it is precisely exercising the users' own will that almost all their basic rights, especially the right to free decision, are related to. ${ }^{31}$

When questioned concerning rules for protection against bias and negative assessment one respondent realized that her institution does not have them at all. Other social workers were generally satisfied with how the rules are used in practice. In several cases they immediately afterwards admitted that the public attitude to service users tends to be negative and that in spheres of everyday life users do not realize themselves as their peers who do not use the social service do. These facts indicate that in the sphere of protecting users from bias and negative assessment there is space for improvement. Positive public attitude to social services users and their self-realization in spheres of everyday life comparable to that of their peers are listed by Čamský as examples of good practice in the sphere of protecting clients from bias and negative assessment. $^{32}$

All respondents are satisfied with the form of rules for preventing situations in which users' rights could be violated, both with their effectiveness (ability to effectively prevent violation of users' rights) and their use in practice. One of the respondents stated that "it is enough that all employees get used to it and respect it." This statement can also be interpreted to the effect that before the rules were introduced employee practice was different, it was therefore necessary to get used to them. This answer may also indicate that the rules are created without participation of employees in direct care. Thus we again approach the topic of the level of professionalism of individual social workers. A frequent problem listed by social workers from residential facilities is that on the whole SQSS are not accepted by all employees. They specifically cited situations when the medical personnel partially or fully ignore them because they take them to be an "invention" of the institution's social section. This situation is extremely difficult to solve and not only the social workers but also the management must take part in the solution.

\footnotetext{
30 Cf. @ Úmluva o právech osob se zdravotním postižením, 13. 12. 2006 (on-line), dostupné na: http://www.mpsv.cz/files/clanky/10774/ umluva_CJ_rev.pdf, retrieved September 29, 2013.

31 Cf. Dagmar KRUTILOVÁ, Sociální služby: tvorba a zavádění Standardi̊ kvality poskytovaných sociálních služeb, p. 61; Jiří SOBEK, Lidská práva v každodennim životě lidí s mentálním postižením, p. 61; Pavel ČÁMSKÝ - Jan SEMBDNER - Dagmar KRUTILOVÁ, Sociální služby v ČR v teorii a praxi, p. 95.

32 Cf. Pavel ČÁMSKÝ - Jan SEMBDNER - Dagmar KRUTILOVÁ, Sociální služby v ČR v teorii a praxi, pp. 86-88.
} 
The ability to communicate with various types of users is a key competency of a good social worker. ${ }^{33}$ Answers to questions focusing on communication with persons with impaired communication ability were (with the exception of one facility where this area was well developed) inconsistent and reflected the workers' lack of certainty in this sphere. Some facilities allegedly had a special methodology, but the workers' answers were vague and imprecise. In some facilities they were aware of the need for a methodology but admitted that they had barely started and developing a special methodology and communication aids for communicating with users with impaired communication ability will take a long time. Employing techniques of augmentative and alternative communication is infrequent among social workers (approximately a quarter of the respondents) and sufficient attention and care is not paid to persons with impaired communication ability to decrease or eliminate their communication deficiency. One respondent stated that he deals with an applicant with impaired communication ability in the same way as he deals with an applicant without impaired communication ability!

When asked whether they deal directly with the applicants or with their escorts (family, friends) all respondents stated that they deal directly with the applicant. However, in one interview additional questions showed that it often happens that the social worker does not even meet the applicant in person and communicates only with relatives. He meets the applicant in person for the first time when she is beginning her stay in the facility. This is obvious violation of several fundamental human rights, including right to free decision. The fact that respondents answer direct questions differently than they answer additional or other questions indicates their effort to make themselves better in the interview, preliminary distrust towards an outsider conducting an interview and asking questions concerning sensitive topics (which the question of respecting human rights in an organization definitely is), or also an output of perhaps the first deeper reflection of the topic, where the interview brought up the opportunity to think and examine the issue of SQSS, as the text cited above confirms. One social worker became aware of the deficiencies in meeting SQSS in her organization only as a result of the interview. If the second suggested option were true, it would mean that workers are able to realize the true state of protecting the human rights of the users of their service and it would be enough "merely" to proceed in deepening the workers' reflection of the area and implement a remedy.

According to workers' statements individual service planning in most facilities worked fine or with some minor problems, but in the course of the interview more than half the respondents eventually admitted serious problems. As the most frequent difficulty workers described the problem of formulating a personal goal with the user, they also stated uneasiness over compulsory plan revision. In one facility there was almost no individual planning at all, workers had a markedly negative attitude or even antipathy to it. Such planning required far too much administrative work, which the workers considered to be lost time. A worker stated that users mostly did not participate in the planning, were not aware of their personal goals and did not work towards fulfilling them. According to her, individual plans do not evolve in time, are not evaluated, revised, or changed. As the respondent stated, planning takes place on paper, not in practice. In the interviews respondents often noted that it would be necessary and appropriate, if there were different kinds of individual planning for individual types of services. One respondent mentioned a situation where field service workers distributing lunches wrestle with administratively demanding individual planning, which the clients often reject and say that they only want a lunch delivery. However, social workers can adjust the whole process of

33 Cf. Oldřich MATOUŠEK a kol., Metody a ř́zení sociální práce, Praha: Portál, 2008, p. 15; Zuzana HAVRDOVÁ, Kompetence v praxi sociální práce: metodická př́ručka pro učitele a supervizory v sociální práci, Praha: Osmium, 1999, p. 51. 
individual planning to the users' needs and type of service. If frequent and grave difficulties occur in the process of individual planning, they can re-adjust the whole process to suit the organization and all persons involved. As an expertly prepared professional, a social worker ought to be capable of that, since it involves primarily applying methods and techniques of social work with individuals.

\section{Protecting the rights of clients in practice}

What means should then be used to ensure that the theoretical protection of clients' rights grounded in the standards takes place in practice? Inspecting the quality of social services is undoubtedly an important tool, yet in some facilities (especially residential ones) users' rights are still violated, as stated e.g. by the public guardian of rights in his report from visits to social services facilities for the elderly, who are one of the most sensitive groups of users from the point of view of upholding human rights. The ombudsman states: "Some of the foremost problems facilities with this clientele ought to focus on are preventing malnutrition, securing the right to privacy and to freedom of movement." ${ }^{34}$ Mátl and Jabưrková offer the plausible explanation that setting up standards in general does not entail sufficient pressure for change. ${ }^{35}$ During the probe focusing on protecting users' rights in SQSS one respondent told us that a several-days-long inspection concerning violating clients' rights generally does not come. When asked what (other than the written rules) she would do to ensure that clients' rights are protected she answered that it would be good to utilize students who are completing their work experience in the facility and therefore come there on a long-term basis. These students would as part of their work experience provide the facility with feedback concerning protection of users' rights; this would be fairly objective since they come from the outside and at the same time have expert qualification, they are not employed by the facility but have spent sufficient time there to recognize violation of users' rights or signals indicating it. Employees are also more open and less alert in the presence of students than in the presence of inspectors. This solution is also financially undemanding.

Another means of ensuring the protection of users' rights in practice suggested by social workers in six interviews of the seven carried out as part of the probe was that the whole workteam should intensively take part in the creation of methodology, using interviews, debates, brainstorming, discussions on the topic. It is important that workers in direct care are present, since they know the risk situations in practice and can contribute valuable insights. Methodology should not be designed by an outsider who does not personally work with service users, much less should methodology development be commissioned to a private firm or external expert. The methodology should derive "from practice" and be developed by the whole team, since only that will ensure that rules, principles, and procedures it comprises will really be upheld and "lived". The workers will identify with them and they will not remain merely "on paper". A methodology which is the product of team work of all workers is more efficient in protecting users' rights than a methodology developed by an external expert, which is not custom-designed for the organization and does not capture all spheres of users' human rights protection specific to the organization. Thus in our view a methodology designed "from a desk" either exemplifies the social workers' lack of professional competence, since such methodology does not accord with the conception of human being in social work, is not consistent with the ethi-

34 Cf. Pavel VARVAŘOVSKÝ, Zpráva z návštěvy zař́zení: zařízení sociálních služeb pro seniory, Veřejný ochránce práv, 2013, p. 17. At http:// www.ochrance.cz/fileadmin/user_upload/ochrana_osob/2013/zarizeni-socialnich-sluzeb-shrnuti.pdf, retrieved September 25, 2013.

35 Cf. Ondřej MÁTL - Milena JABŮRKOVÁ, Kvalita péče o seniory, p. 45. 
cal code of social workers and, last but not least, indicates the social workers' lack of interest in the sphere of users' human rights, or it manifests a specific conception of social work merely as "practical lay help", i.e., without the need for a deeper understanding of the points of departure and goals of social work. (Do social workers give up on professional education, or is the education itself deficient?) On the other hand, the development of SQSS was conditioned precisely by a tendency to increase the quality of social services. We could also argue about other factors such as vocation motivation and others.

According to social workers the probe brought up several other means of ensuring protection of users' rights. In three interviews the worker's personality profile was mentioned: "Because some people are simply not suitable for social work," one respondent noted the importance of practically training new workers at the workplace, the importance of going through a "round" with more experienced colleagues in various positions who will point potential risk situations out to the new colleague, advise her on how to proceed in such situations, and pass valuable practical experience on to her. According to three respondents it is a matter of course that a new worker studies the methodology in detail, but it is also necessary to have contact with practice in which the new worker will be able to test their application in practice under the supervision and with support of colleagues.

Another means that was not mentioned by the workers but we believe to be important is quality supervision and mental hygiene. Educating workers in the sphere of SQSS is also an effective means of ensuring protection of clients' rights, but only if the worker leaves with insight and skills, not just an exposition of the legislation, "guaranteed recipe", and fulfilled educational condition. One other possibility came up in the interviews - discussion and sharing experience among workers and organizations. In one facility where an interview was conducted they have a highly developed system of individual planning custom-made for users with impaired communication ability, while in another facility where there is a different type of clients but also with impaired communication ability individual planning poses problems so grave that they render it dysfunctional. In the workers in these facilities exchanged experience, positive change in the second facility would result. But such mutual exchange of experience runs up against a difficulty - there is no interest in it. Every facility also protects its methodology and does not want to publish it, since it took many hours of work to design. This is the case in most organizations, as we can confirm e.g. from six-years-long experience with students of master's degree in social work in distance form who, as part of one subject evaluation paper, are asked to comment on the methodology of their or other organizations. Organizations are not willing to make their methodology available for this purpose, not even in anonymized form. Only a few organizations welcome this possibility of external feedback and perceive it as a development opportunity. We fear that this again can be interpreted as a consequence of social workers' lack of professionalism, besides other causes such as competition among organizations "fighting" for clients, reputation, and subsidies in the social services market. This brings us to another important condition for securing the human rights of clients. Social work should be performed by qualified social workers whose competencies include recognition and protection of human rights, upholding users' human dignity, knowledge of the legislation and of course of ethics, since according to Opatrný social work is in a sense "practical ethics". ${ }^{36}$

36 Cf. Michal OPATRNÝ, Sociální práce a teologie, Praha: Vyšehrad, 2013, p. 216. 


\section{Present situation and forthcoming changes}

Boosting protection of users' rights is the goal of the current MoLSA project Innovation of Quality of Social Services. One of its principles is transition from inspecting quality management to inspecting rights protection. ${ }^{37}$ Within the planned innovation of standards emphasis is placed on boosting the protection of users' rights, since, according to Miler, criticism of the administrative load connected with SQSS indicates a lack of understanding of the necessity to formulate written rules as process result, which, as Sýkorová adds, eventually leads to formally implementing the standards. ${ }^{38}$

The document Innovation of Requirements for the Quality of Social Services, which is an output of the Individual project of MoLSA - Innovation of the System of Quality of Social Services, points out the shortcomings of the current version of SQSS from 2006 and proposes revision and change. In connection with protecting users' rights it points out an inconsistency: according to current criteria of standard no. 2 it is required to elaborate rules to prevent situations in which stigmatization, violating persons' rights, or conflict of interests might occur, while the law concerning social services requires that conditions are created allowing users to fulfil their rights, that the extent and form of assistance always uphold the human dignity of persons, and that upholding the basic human rights and freedoms of persons is always consistently ensured. The requirement to produce rules in which undesirable situations are negatively defined is to be changed in accordance with the law concerning social services to a positive formulation calling for creating conditions needed for upholding human rights and respecting human dignity. In standard no. 2 there will newly appear support in deciding, a new means of value fulfilment inspection, and a specification of the concept of social incorporation. On the whole the standards will pay more attention to positively formulating requirements and superfluous requirements to elaborate rules will be eliminated. ${ }^{39}$

\section{Conclusion}

On the whole social workers have a positive attitude to the standards, they view implementing them as beneficial for their work for several reasons, they especially perceive the importance of protecting the human rights and freedoms of users. The values protected by SQSS are not perceived by the workers generally, rather in the form of specific situations they encounter as part of their day-to-day practice, such as e.g. the value of human dignity which workers protect by consistently upholding users' privacy. However, in the sphere of applying standards related to the topic of protecting users' human rights and freedoms grave shortcomings were identified $^{40}$ (the extent varies in different service types) that may indicate insufficient professional knowledge and skills on the part of social workers and violation of ethical code. As stated by Musil, many focus on what they expect of the standards, i.e., their pre-conception, rather than on what the text of the standards requires. ${ }^{41}$ As a result, social workers as professionals do not sufficiently reflect on the human rights and freedoms of users in practice and are not capable of

37 Cf. Dana KOŘÍNKOVÁ - Jan STRNAD, Klíčové prvky ochrany práv uživatelů sociálních služeb [pdf], Revize standardů kvality sociálních služeb v kontextu projektu Inovace systému kvality sociálních služeb, konference konaná v Praze dne 20. 6. 2013.

38 Cf. Ondřej MÁTL - Milena JABŮRKOVÁ, Kvalita péče o seniory, p. 46.

39 Cf. Inovace požadavků na kvalitu sociálních služeb. Druhý návrh věcného řešení 30. dubna 2013, Ministerstvo práce a sociálních věcí. At http:// www.mpsv.cz/files/clanky/15275/inovace.pdf, retrieved September 25, 2013.

40 An ideal tool for determining the real state of protecting users' rights might be concerned observation, as confirmed by one of the respondents.

41 Cf. Ondřej MÁTL - Milena JABŮRKOVÁ, Kvalita péče o seniory, p. 46. 
efficiently ensuring that users' human rights and freedoms are upheld in their organization. ${ }^{42}$ Now it is necessary to ask about the causes, which may inhere in many spheres: from the manner and content of social workers' education through the management of specific social services to the state of the civil society. ${ }^{43}$

In order to assess how efficient the standards are in protecting the human rights of users we must distinguish between theoretical elaboration of methodology (which according to respondents is highly developed) and its actual use in practice. In our view the standards should focus more on the actual process of methodology development and in accordance with the planned innovation of SQSS on creating conditions for upholding human rights and respecting human dignity. The system of inspecting how users' rights are protected should also be made more efficient.

\section{Social Workers' Interpretation of and Attitude to Standards for Quality in Social Services with Focus on Human Rights}

Abstract The text deals with the difficult implementation of SQSS in the practice of social work with focus on human rights. The results of a probe have shown that social workers are aware of the importance of protecting the human rights and freedoms of users. But in the sphere of applying standards related to protecting the human rights and freedoms of users deficiencies were identified, which could indicate that social workers have insufficient professional knowledge and skills and do not comply with the ethical code. The text describes the current situation and proposes changes.

Key words standards for quality in social services, human rights

42 The main sphere for development we identified is enabling communication in intelligible form.

43 An infelicitous consequence of the public attitude to social services users and insufficient citizens' commitment may be the dire lack of volunteers in social services, especially as compared to Western countries (cf. EUROPEAN VOLUNTEER CENTRE, Volunteering Infrastructure in Europe, Brussels: CEV - European Volunteer Centre, 2012. At http://www.dobrovolnik.cz/res/data/021/002564.pdf, retrieved December12, 2013), who could be helpful in developing the quality of social services, since one of the most common arguments employed to justify many problem situations in social work in general is lack of money (even for maintaining or ensuring a sufficient number of workers for the given service) and low financial reward of workers. 